\title{
Dynamical Manifestations of Rock Pressure and Mining-Induced Seismicity at Khibiny Apatite Mines in the Kola Peninsula
}

\author{
A.A. Kozyrev, V.A. Maltsev, V.I. Panin, V.V. Rybin Mining Institute, Kola Science Centre, Russian Academy of Sciences, Russia \\ V.S. Svinin Joint Stock Company "Apatit", Russia
}

Presented is the geodynamical situation at Khibiny apatite mines in the Kola Peninsula (Murmansk region, Russia), which, along with other companies of mining-industrial infrastructure make up the natural-engineering system "Khibiny". The dynamic of rockbursts and mining-induced earthquakes in geomechanical area of mines, and description of the most intense events are given. The classification of dynamical manifestations at mines is suggested.

\section{INTRODUCTION}

The issue of the mining-induced seismicity is a crucial one for many mining regions, including the Khibiny apatite mines in the Kola Peninsula (Murmansk region, Russia) (Kozyrev et al., 2000; Kozyrev et al., 2001).

As a result of many years (the "Apatite" JS company will have operated for 75 years by November 2004) of a large scale mining of apatite deposits in the southern part of Khibiny massif there has formed a natural-engineering system (NES) "Khibiny" (Fig. 1), which includes 5 mines, 2 concentrating mills, power supply and transportation facilities, as well as some commercial facilities, which interact with each other and the environment in rather a complex way both functionally and ecologically. The "Khibiny" NES is a typical modern natural-engineering system, in which the entire complex of the most urgent engineering-ecological problems is reflected. However, in this case, it is only the matter of consequences of disturbing the geodynamical balance of the region's geological medium, and it is exactly from this position that the condition and evolution of the "Khibiny" NES are considered, , although there are some other equally urgent ecological problems in the region.

Some elements of the system play a nonequivalent part in the formation of the resulting state of the "Khibiny" NES. However, the primary contributor here is, without doubt, the mining operation. In turn, High activity of new-tectonic processes and, as a result, high natural stress of rockmasses (geological medium), in which mining operations take place; the typical peculiarities of the mining operation conditions within this system are as follows:

- Most large scale mining, resulting in irretrievable excavation of considerable volumes (up to 50 million t. /year) of mineral, as well as transportation of huge amount (up to 160 million t./year) of rock from the deposit to the sites of temporary or permanent storing,

- Intense technologic dynamical impacts on the rockmass, on account of peculiarities of mining technology application along with huge blasting (up to $350 \mathrm{t}$. of trinitrotoluol equivalent).

Large-scale mining of apatite deposits in the Khibiny massif resulted in the total increase of tectonic activity of the region.

At the same time, as the intensity of mining operations and the total volume of mineral excavation increase a few stages of geodynamical situation alteration can be seen in this region (Kozyrev et al., 2001).

\section{CHARACTERISTICS OF MINING-INDUCED SEISMICITY AT APATITE MINES}

\subsection{General Characteristics and Reasons}

The time variation change of dynamical phenomena at apatite mines since the late 70-ies till now are presented in Figure 2. An important specific feature of the modern state of mining operations in the region is the joining of mined out areas of separate mines. The mined out areas of Kirovsk and Yukssporr mines and Saami pit form a unified extended excavation. The Rassvumchorr mine, separated from the Yukssporr mine with a narrow valley, has an underground mine below the north-western wall of the Open pit of Tsentralny mine. Just next to the Open pit of Tsentralny mine there is an open pit of the Eastern mine. Thus, the area of mining operations is an uninterrupted band going over all ore-bodies of apatitenepheline deposits of about $25 \mathrm{~km}$ lengthwise along strike and $1.5 \mathrm{~km}$ wide down - dip.

Due to the situation, to understand in the right way the process of mining operation impact on the change of the natural level of the stress state of the massif, it is important to introduce the concept of "unified geodynamical space" of the entire system of mines and facilities, connected with mining production, since the redistribution of ore and rockmasses takes place both during the ore excavation (irretrievable excavation) and during stripping operations, dumping to spoil, ore stocking, formation of tailing dumps of concentrating mills, ash dumping and coal stocking at power plants etc. The determination of the dimensions of the unified geodynamical space, and correspondingly of the natural-engineering system is an important scientific and practical task. Then, by the unified geodynamical space one should understand the zone of the upper part of the Earth's crust, within the range of which the impact of mininginduced factors on the natural level of the stress state results in its considerable change (up to $10 \%$ ), which, in turn, may stipulate the generation of mining-induced disasters.

The dumping to spoil affects the parameters of the stress state, thus, influencing the seismicity of the entire Khibiny massif. According to "Apatite" company data, by January, 1, 1995, the United Kirovsk mine dumped 57 million t., the Central mine -722 million $t$., Rassvumchorr mine -25 million t., the Eastern mine - 388 million $t$. of rock. The amount of this scale, concentrated in a small area, modify considerably the state of the rockmass.

The most powerful mining-induced manifestations of seismicity are located in the region in zones of mining operations as such, however, some activation of the 


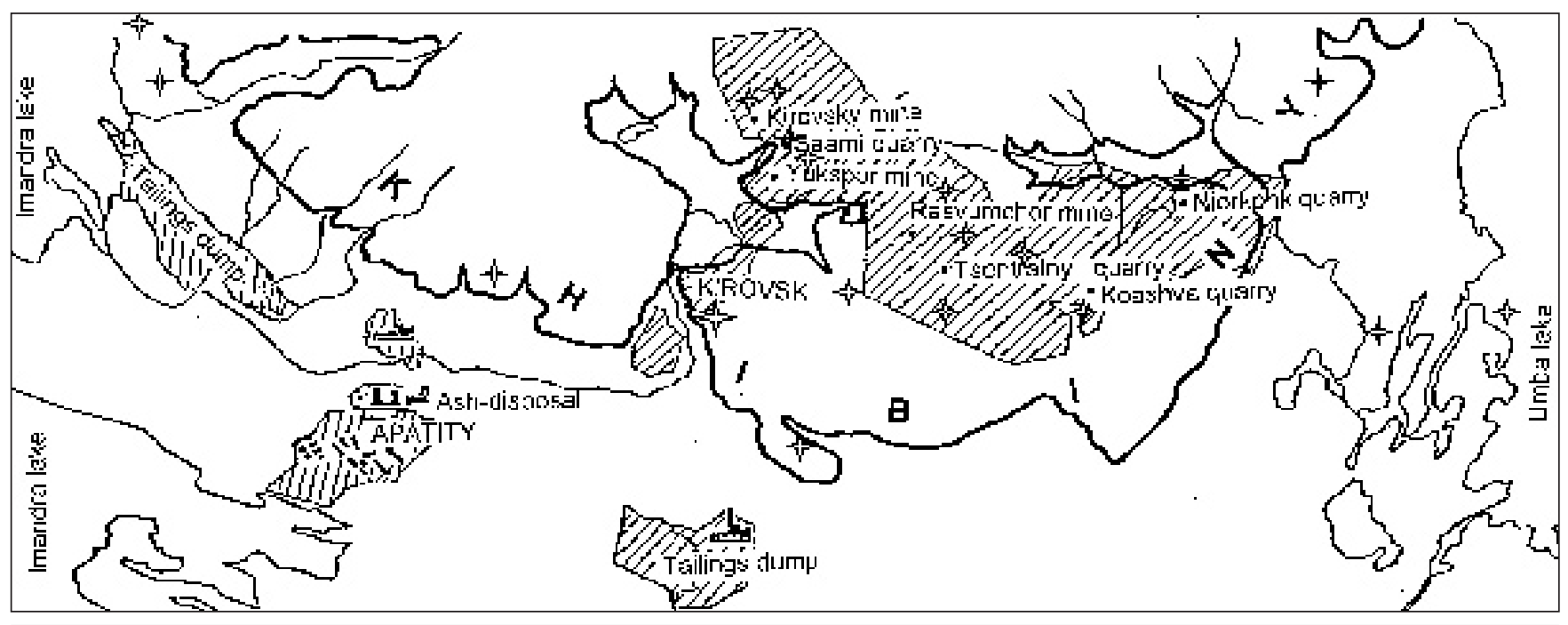

FIG. 1 The plan of the natural-engineering system "Khibiny" - - seismic events at M>1

seismicity has been registered in the south part of Khibiny massif, in the territory of ANOF-2 concentrating mill (Fig. 1) (Kremenetskaya and Tryapitsin, 1992), where the amount of dumped tailings can be compared to that of waste rock dumps.

Mining operations have reached such volumes, which stipulated a considerable increase of mining-induced impact on the tectonically stressed Khibiny massif. All this is manifested through quick shifts of blocks in the upper part of the Earth crust, generation of large zones of caving on the surface, tension rupture, i.e., in fact, through formation of new forms of topography (Fig. 3). At the same time the stress degree of some structural blocks is increased sharply, which, in turn, results in an increased seicmicity level. So, during the last five years the level of the induced seicmicity in the Khibiny massif has increased by more than an order of magnitude (in energy). Since 1978, there were registered more than 50 rockbursts in Khibiny underground mines, 11 of which, with released energy $E=10^{7}-10^{12} \mathrm{~J}$, were classed as -tectonic rockbursts, other 11 - mining-induced earthquakes, which entailed considerable destructions of mining workings, underground communications and mechanisms, inflicting damage to industrial facilities and dwelling buildings in Kukisvumchorr village. According to the data of automated system of the massif seismicity monitoring, weak shocks $\left(\mathrm{E}<10^{4} \mathrm{~J}\right)$ are registered daily.

\subsection{Description of Consequences of Dynamical Phenomena}

All rockbursts, tectonic rockbursts and mining-induced earthquakes registered at Khibiny mines are presented in the Appendix.

The first rockburst at Khibiny mines was registered on the 21 July, 1964 during the sinking of an orepass № 3 of the open pit of Tsentralny mine. It was accompanied with the destruction of lining in the orepass (metal mesh fixed by anchor) and with rock slabs outburst, with slabs' maximum weight making 0.8 and 1.5 tons (Markov, 1978). The seismic effect of this phenomenon was registered at the "Apatity" seismic station, which was located at about $20 \mathrm{~km}$ from the place of this phenomenon manifestation, so later this rockburst was qualified as tectonic rockburst.

Later on, when mining a block-pillar at the first depth level $+322 \mathrm{~m}$ (located below the level of surrounding valleys) of the Kirovsk mine during the period from 1969 to 1979 two powerful rockbursts occurred with $90-120$ t of rock outburst

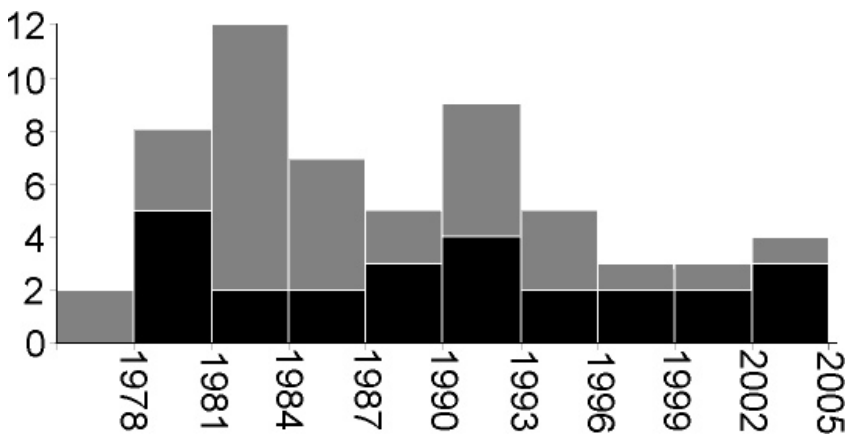

FIG. 2 Distribution of rockbursts year to year at "Apatite" mines $\square$ - rockbursts; $\square$ - tectonic rockbursts and mininginduced earthquakes

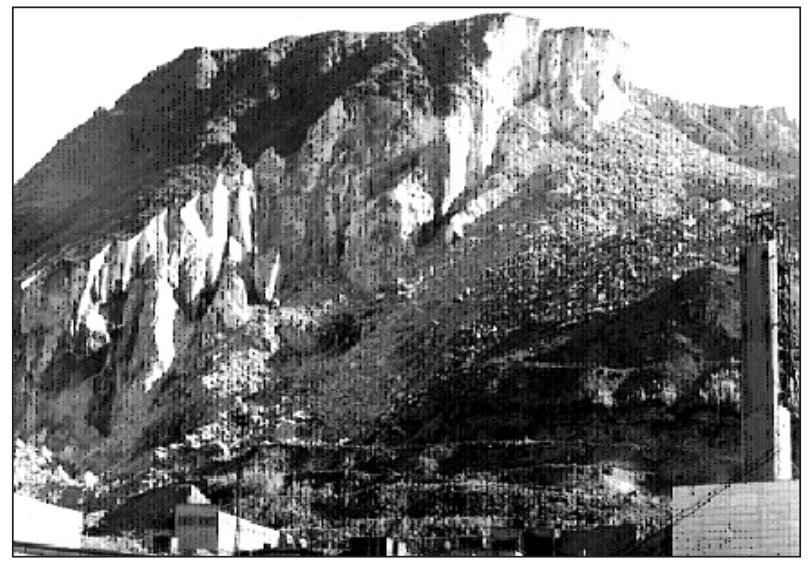

FIG. 3 View of caving of the earth surface, impacted by underground mining operation

(Fig. 4) and one tectonic rockburst, manifested as a shifting of rock blocks, which destroyed the concrete lining. As a result, the mine workings of the block bottom were destroyed, which made the further ore mining impossible in this block (Markov, 1977; Panassenko, 1983).

The development of operations at a yet deeper level $+252 \mathrm{~m}$ of the same mine, when mining operations were performed near the intersection of several geological faults, a series of rockbursts and mining-induced earthquakes occurred in 
1981-1982, which is an evidence of sharp increase of seismic activity in the mine: both the number and energy release of dynamical phenomena increased. The most intensive of them took place on January 8, August 18 and September 29 1981, which caused appreciable shakings in underground workings and on the surface near the mines, of $\mathrm{M}=3-4$, which enables us to qualify them as mining-induced earthquakes. Small depth of their epicenters, being, by instrumental estimation, of an order of $2-3 \mathrm{~km}$ and their being evidently confined to the zone of stoping operations make one believe, that they were a consequence of the mining operations carried out, for a long time, in this region (Panassenko, 1983).

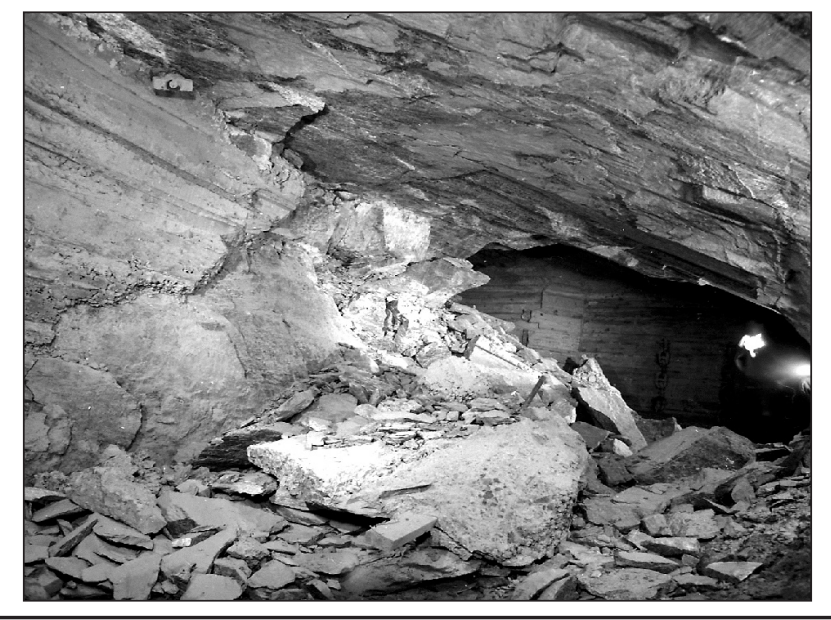

FIG. 4 Rockburst damage

On May 17, 1981, there was registered a series of shocks, connected with technological blasting. Between 7 h. 30 min and $12 \mathrm{~h} .02 \mathrm{~min}$, Moscow time, there were performed 7 blasts of different intensity at apatite mines. Soon after the first blasts there started shocks in the rockmass, which lasted for about 14 hours. Eighteen of the most powerful of them were registered by "Apatity" seismic station. Later on this series was qualified as a mining-induced earthquake.

On August 29, 1982, at 9 h. 33 min. 34 sec. Moscow time, the seismic station "Apatity" registered a powerful shock near Kukissvumchorr village, the epicenter of this shock was located at the depth no more than $5 \mathrm{~km}$. The intensity of shakings in the village of Kukissvumchorr and the town of Kirovsk exceeded 5 points. The shakings were felt within the neither radius of nor less than $20-25 \mathrm{~km}$ from the epicenter. The shakings were accompanied with a strong boom and vibration of buildings. The examination of workings of the Kirovsk mine revealed a narrow band of concrete lining scaling, along the wall and roof of the mine workings. This is an evidence of the fact that the shifting along the formed fault of the rockmass.

The most powerful mining-induced earthquake took place on April 16, 1989. When examining mining workings after the earthquake, it was found, that along the fault, which was represented by aegirine vein $15-25 \mathrm{~cm}$ thick, there formed a fracture, with the north-west strike, the north-east dip with the mean angle $35^{\circ}$. All along its way the fracture is almost parallel with the vein, which was a little different in strength before the earthquake from the rest of the mass, except some areas with underdeveloped oxidation. The fracture, which is as wide as $2-5 \mathrm{~cm}$ at some parts, has the fresh traces (furrows) of friction and finely ground material (friction clay), which allows one to have an idea of the direction and amplitude of the shifting. In some parts the fracture is ramified and forms a few sub parallel fractures. In the workings, crossed by the newly formed fracture, rock slabs falling occurred, with concrete lining destroyed, cat-cranes and railway tracks deformed (Fig. 5). The main opening and the rise shaft were damaged, where they both cross the fracture, the concrete lining, streaks and guides are deformed.

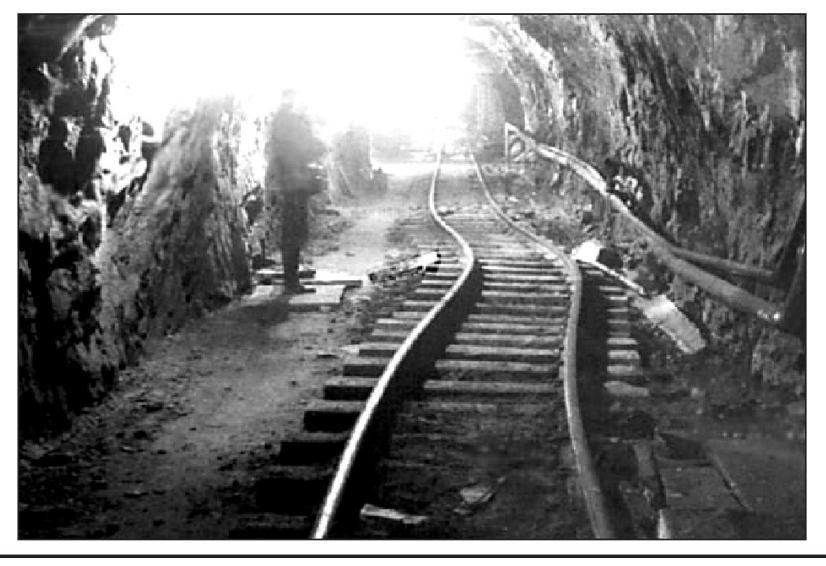

FIG. 5 Deformation of tracks in a drift as a result of mininginduced earthquake 16.04.89

In the plan, the strike extension of the fracture makes $1.1 \mathrm{~km}$. The fracture is registered in the section, limited by almost vertical faults. The traceable depth of the formed fracture at three different levels makes $+322,+252,+172$, which means it is traced from the surface for more than 200 $\mathrm{m}$ deep. The surveyor measurements showed, there had occurred a thrust, the amplitude of which at the horizons $+322,+252,+172 \mathrm{~m}$ makes 8-9, 5-6, 1.5-3 cm respectively.

At the Yukssporr mine, the most powerful event occurred on June 19,1984 , it was a tectonic rockburst again in the joint section of a block-pillar of level $+530 \mathrm{~m}$. As a result of rock blocks shifting over the monchekite dyke, that crossed the block-pillar cornerwise, there were destroyed a few mining workings at three sublevels.

When mining another block-pillar, yet at the level $+252 \mathrm{~m}$ of the Kirovsk mine, when the distance between stoping areas became minimum and only measured $70 \mathrm{~m}$ (with stoping areas being in the plan $100 \times 200 \mathrm{~m}$ and $200 \times 300 \mathrm{~m}$ ) on the 17 of November 1993 two rock bursts and a mining-induced earthquake, $\mathrm{M}=4$ occurred in the block-pillar. A fracture crossed the block-pillar remaining between the stoping areas. Then two more events followed on December 9 and 12, 1993 with magnitudes of 1.7 and 3 respectively.

After the mining of block-pillar at the Kirovsk mine was over, the seismicity level dropped considerably.

The beginning of mining of the next, one of the deepest, level $+172 \mathrm{~m}$ of the Kirovsk mine and formation of unified stoping area of Kirovsk and Yukssporr mines, the development of operations at some deep horizons of Rassvumchorr mine and its merging with the Open pit of Tsentralny mine resulted again in the increase of the seismicity in the region, even in spite of considerable drop in volume of apatite ore mining in the 90's of the last century. During the last decade at Khibiny mines 1- 2 powerful dynamical phenomena of rock tectonic bursts type and mining-induced earthquakes type are registered annually.

\section{CLASSIFICATION OF DYNAMICAL PHENOMENA IN MINES}

Although the mining-induced seismicity problem is of a long date, there has not yet been any generally accepted classification of dynamical phenomena in mines, so often different terms are used to refer to similar events. The most uncertain terms are "tectonic rockburst" and "mininginduced earthquakes". The unified physical nature of all dynamical phenomena in mines is generally accepted - from 
rock spalling in mining workings to powerful earthquakes, so in most classifications the main sign of identification is the energy of dynamical event (Seismicity, 2002). The separation of all dynamical manifestation in mines into two groups has spread the most as suggested by Johnson (1989):

- Rockbursts as such, induced by local stress concentrations in mining workings and elements of the development systems,

- Tectonic rockbursts and mining-induced earthquakes, induced by sudden shift under the influence of mining operations, large blocks of rock following tectonic faults or different geological boundaries.

However, important for the mining practice is not so much the mechanism or even the energy of dynamical event, but its direct impact on the technological process. In this case, the same phenomena may have most different consequences for mining operations. If all phenomena are referred to with one term "catastrophe", then, we believe, as far as the mining-technical practice is concerned catastrophes may be considered within three main aspects (Kozyrev et al. 2001):

- Catastrophes physically understood as fracturing in rockmass (is characterized by the energy of seismic event),

- Catastrophes understood geomechanically, as some kinds of rock pressure manifestation in mine workings (scaling, spalling, dynamical slabbing of rock, rockbursts, tectonic rockbursts, mining-induced earthquakes),

- Catastrophes in the technological sense of the term, as technological consequences of rock pressure in mining workings (their characteristics depend on how serious are the consequences for mining operation).

Let us illustrate the classification of catastrophes as technically understood, using some examples.

Let us admit there occur same types of destruction and of equal size in two mine workings used for different purposes. So, in an airway mine working, in the absence of people, mechanisms and transport communications, the destruction of its contour, in case it had not diminished significantly the cross-section of the working, would not influence the mine operation. In a haulageway mine working, being buried in rock pieces, the destruction would result in the suspension of work in this area of the mine, for as long as it is needed to remove the destroyed rock pieces. When the same kind of destruction takes place in a face of drift damaging equipment or people, the consequences will be much worse.

Another example shows an evident dependence of the severity degree on the extent of destruction. Let us assume that destructions of various extent take place in the same airway mine working. If there is only one loosened rock, then, it is evident that there will be no consequences for normal mine working operation. However, if there is a rockburst with destructions, resulting in diminishing the airway cross-section, needed for normal flow of the ventilation air, the operation in this part of the mine would be stopped and it would require time and some expenses to remove the destroyed rock.

Finally, the third example shows, how a destruction, being of the same physical nature, results in significantly different consequences from technological point of view, in mining workings of different size. Let there be three mine workings, same in shape of the cross-section, but different in size, with a man working in them. It is obvious, that in the continuous solid rockmass, the slabbing formation will be taking place according to the same mechanics, with geometric proportions observed between the slabbing size and the dimensions of the working. However, the danger for man substantially increases as the size of slab increases. For example, in a working $2 \mathrm{~m}$ high the falling of a slab with size up to $0.5 \times 0.5 \mathrm{~m}$ and $2 \mathrm{~cm}$ thick is almost not dangerous for man (0 risk level), in a working 3-4 $\mathrm{m}$ high, the falling of a slab measuring $1 \times 1 \mathrm{~m}$ and 5-7 cm thick from 1-2 $\mathrm{m}$ height may result in serious traumas (the level of risk 5-10 points). In a working more than $4 \mathrm{~m}$ high, the linear dimensions of a slab reach $3 \mathrm{~m}$, with the thickness of 0.3-0.5 $\mathrm{m}$. Such a slab falling leads to lethal results (the risk level exceeds 10 points).

The intensity of destructions in mining workings and their severity level depend on the energy of seismic event and the distance from the guarded object to its focus. Due to this, it is important to divide all consequences of dynamical events in three groups:

- Neutral ones, i.e. not influencing mining workings and technological process;

- Local ones, occurring in mining workings or separate elements of mining system;

- Regional mining-induced earthquakes, taking place over a considerable area and substantially affecting the technological process.

The events of the first group do not represent any direct threat to mining operations, however, they can serve as an indicator of geodynamical condition of geological medium within the geomechanical space of the mine. The best results have been obtained so far, when solving the problem of consequences of the second group of dynamical events, the source of which is mainly, rockbursts. When carrying out mining operations, while observing corresponding technological regulations, this danger can be substantially reduced or virtually averted. The third group nowadays, represents the most serious threat to all mining-technical operations, including the life mining workers, while the problem of controlling the risk remains vital.

\section{CONTROLLING THE RISKS OF DYNAMICAL PHENOMENA IN MINES}

The control of a mining-induced earthquakes risk in mines is similar to the control of any natural risks and it consists in the forecasting of critical states of geological medium in the region of mining operations and in the application of corresponding prophylactic measures (Seismicity, 2002).

The forecasting of critical states is based on the analysis of geology and tectonics of the mining region, on the implementation of a preliminary assessment of the dimensions of energy saturated (high-stressed) zones in the geological medium, using corresponding calculation methods, as well as on geodynamical monitoring of those zones. According to the national and foreign experience, the most informative forecasting precursors of spatial-temporal coordinates of the geological medium critical state are parameters of seismicacoustic regime and processes of the rockmass deformation.

The basic goals of prophylactic measures consist in enhancement of adaptation resource of NES as well as the controlled withdrawal of energy saturated areas from the critical state. The first goal is achieved by the optimum planning of the procedure of mining operation implementation and basic technological processes, mainly the periodicity of blasting operations during stoping breaking. Withdrawal of some area of geological medium from the critical state is achieved through a complex of organizational and technological measures: by stopping mining operations on this area and its "decommissioning", through application of various kinds of relief measures, which efficiency can also be checked experimentally, using certain methods of geodynamical monitoring. 


\section{CONCLUSION}

The large scale mining operations in highly-stressed hard rockmass affect considerably the geodynamical regime of geological medium, which can be seen primarily, by the large number of dynamical events of wide energetic scale in the geomechanical space of mines. This is confirmed by the practice of Khibiny apatite deposits mining, where during the many years of mining a natural-engineering system "Khibiny" has formed, while it is a unique natural laboratory for developing methods of forecasting and prophylactics of mining-induced seismicity during mining operations. When classifying and identifying dynamical phenomena in mines, one has to take into consideration the risk level of these phenomena for technological process of mining. Only the level of risk should determine the strategy and tactics of forecasting and prophylactics of mining-induced seismicity.

\section{ACKNOWLEDGMENTS}

This research was supported by Russian Foundation of Basic Research, Grants N 03-05-65258.

\section{REFERENCES}

Kozyrev, A.A., Panin, V.I. and Maltsev, V.A. (2000) Study of the dynamical regime of the region under large -scale mining in the apatite-nepheline deposits in the Kola Peninsula, Russia. In Proceedings of MassMin 2000 Brisbane, pp. 799-803.

Kozyrev, A.A., Panin, V.I., Maltsev, V.A., Grigoriev, A.V., Svinin, V.S. and Akkuratov, M.V. (2001) Geological medium monitoring for powerful dynamic events prediction. In Proceedings of RaSiM5 South African Institute of Mining and Metallurgy, pp. 521-527.

Kremenetskaya, E.O. and Tryapitsin, V.M. (1992) Induced seismicity in Khibiny massif (Kola Peninsula). NORSAR Scientific Report, N1, pp. 125-127.

Markov, G.A. (1977) Tectonic stress and rock pressure in mines of Khibiny massif, Leningrad, 213 pages.

Panassenko, G.D. (1983) Technogenic activation of tectonic processes in Khibiny massif, tasks and ways of studying it. Geophysical research in the european north of the USSR, Apatity, pp. 25-38.

Seismicity in mining (2002) Collective of authors. Apatity, Kola Science Centre of RAS, 325 pages.

\section{APPENDIX}

Dynamical phenomena in Khibiny apatite mines

\begin{tabular}{|c|c|c|}
\hline Date & Mine, location & Registered destructions or seismic energy \\
\hline 21.07.64 & Open pit of Tsentralny mine mine, orepass N 3 & $\begin{array}{l}\text { Tectonic rockburst, several sorting plates, each weighing } \\
(0.8-1.5) \mathrm{t} \text {; registered by "Apatity" seismic station }\end{array}$ \\
\hline 03.04.69 & Kirovsk mine, level+322m;block 2/4 interblock cross drift 4 & Rockburst $\approx 90 \mathrm{t}$ \\
\hline 08.10.79 & Kirovsk mine, level $+322 \mathrm{~m}$; haulage cross drift $7^{\mathrm{a}}$ & $\begin{array}{l}\text { Tectonic rockburst, fractures in concrete lining of capital work- } \\
\text { ings; distortion of rail tracks, complete destruction of bottom } \\
\text { workings of the block }\end{array}$ \\
\hline 12.12 .79 & Kirovsk mine, level+322m; haulage cross drift 5 & Rockburst $\approx 120 \mathrm{t}$ \\
\hline 08.01 .81 & Kirovsk mine, shakings at level +322 and $+252 \mathrm{~m}$ & Mining-induced earthquake $M=2,1$ \\
\hline 11.03 .81 & Kirovsk mine, Level+252; block 13/15; scraper drift 1315 & Rockburst $\approx 8 \mathrm{~m}^{3}$ \\
\hline 17.04 .81 & Kirovsk mine, Level+252; block 13/15; scraper drift & Rockburst $\approx 5 \mathrm{~m}^{3}$ \\
\hline 17.05 .81 & $\begin{array}{l}\text { Kirovsk mine, Series of bumps in workings level }+252 \text { and } \\
322 \mathrm{~m}\end{array}$ & Mining-induced earthquake $M=3$ \\
\hline 18.08 .81 & Kirovsk mine, shakings at level +322 and +252 m & Mining-induced earthquake $M=3.2$ \\
\hline 29.09.81 & Kirovsk mine, shakings at level +322 and $+252 \mathrm{~m}$ & Mining-induced earthquake $M=3.1$ \\
\hline 05.03 .82 & Kirovsk mine, Level+252; block 13/15; scraper drift $1314^{a}$ & Rockburst $\approx 3 \mathrm{~m}^{3}$ \\
\hline 12.04 .82 & Kirovsk mine, Level+252; block 13/15; scraper drift $1314^{a}$ & Rockburst $\approx(2-3) \mathrm{m}^{3}$ \\
\hline 16.04 .82 & Kirovsk mine, Level+252; block 13/15; scraper drift $1315^{a}$ & Rockburst $\approx 1 \mathrm{~m}^{3}$ \\
\hline
\end{tabular}




\begin{tabular}{|c|c|c|}
\hline 22.04 .82 & Kirovsk mine, Level+252; block $13 / 15$ & Rockburst $\approx 1.5 \mathrm{~m}^{3}$ \\
\hline 22.04 .82 & Kirovsk mine, Level+252; block $13 / 15$ & Rockburst $\approx 3 \mathrm{~m}^{3}$ \\
\hline 29.08 .82 & Kirovsk mine, Level+252 & Mining-induced earthquake $M=3$ \\
\hline 05.01 .84 & $\begin{array}{l}\text { Yuksspor mine, Level }+530 \mathrm{~m} \text { block } 7 / 9,9^{\mathrm{b}} \text { haulage cross } \\
\text { drift }\end{array}$ & Rockburst $2 \mathrm{~m}^{3}$ \\
\hline 25.01 .84 & $\begin{array}{l}\text { Kirovsk mine, Level+172, working leading to south-east } \\
\text { shaft N } 2\end{array}$ & Rockburst $1.5 \mathrm{~m}^{3}$ \\
\hline 01.02 .84 & $\begin{array}{l}\text { Yuksspor mine, level }+530 \mathrm{~m} \text {, block } 11 / 12,10^{\mathrm{b}} \text { haulage } \\
\text { cross drift }\end{array}$ & Rockburst $1 \mathrm{~m}^{3}$ \\
\hline 26.03 .84 & Kirovsk mine, Level +252 , block $9 / 11,10^{\mathrm{b}}$ cross drift & Rockburst $9 \mathrm{~m}^{3}$ \\
\hline 19.06 .84 & Yuksspor mine, level+530m, block $7 / 11$ & Tectonic rockburst $40 \mathrm{~m}^{3}$ \\
\hline 29.11 .84 & $\begin{array}{l}\text { Yuksspor mine, level }+530 \mathrm{~m} \text {, block } 7 / 11,10^{\mathrm{a}} \text { haulage cross } \\
\text { drift }\end{array}$ & Tectonic rockburst $0.5 \mathrm{~m}^{3}$ \\
\hline 20.02 .86 & Kirovsk mine, Level +172 , by-pass working N 2 & Tectonic rockburst $25 \mathrm{~m}^{3}$ \\
\hline 14.03 .86 & $\begin{array}{l}\text { Yuksspor mine, level }+460 \mathrm{~m} \text {, block } 15 / 17,15^{\mathrm{a}} \text { haulage } \\
\text { cross drift }\end{array}$ & Tectonic rockburst $3 \mathrm{~m}^{3}$ \\
\hline 19.03 .86 & $\begin{array}{l}\text { Kirovsk mine, Level }+172 \text {, by-pass working leading to } \\
\text { technological chamber, pumping chamber (workings were } \\
\text { under sinking) }\end{array}$ & Tectonic rockburst $30 \mathrm{~m}^{3}$ \\
\hline 11.05 .86 & $\begin{array}{l}\text { Kirovsk mine, level }+252 \mathrm{~m} \text {, block } 7 / 9,8^{\mathrm{a}} 12 \text { scraper drifts, } \\
\text { control-air cross drift } \mathrm{N} 11\end{array}$ & $\begin{array}{l}\text { Tectonic rockburst, blocks' advance along the fracture of } \\
\text { Mining-induced origin, } 11 \mathrm{~m}^{3}\end{array}$ \\
\hline 27.11 .86 & Kirovsk mine, Level+252, block $17 / 19,4$ haulage drift & Rockburst $1 \mathrm{~m}^{3}$ \\
\hline 06.02 .87 & Rassvumchorr mine, level $+530 \mathrm{~m}$, block $4 / 77$ haulage drift & Rockburst $4 \mathrm{~m}^{3}$ \\
\hline 16.04 .89 & Kirovsk mine, level $+322 \mathrm{~m},+252 \mathrm{~m},+172 \mathrm{~m}$ & Mining-induced earthquake $M=4,2$ \\
\hline 25.07 .89 & $\begin{array}{l}\text { Kirovsk mine, Level+172, pump working, technological } \\
\text { chamber, by-pass working } N 2\end{array}$ & $\begin{array}{l}\text { Mining-induced earthquake. Fractures and inrushes up to } \\
0.3 \mathrm{~m}^{3} \text { of concrete lining }\end{array}$ \\
\hline 06.04 .90 & $\begin{array}{l}\text { Rassvumchorr mine, level }+530 \mathrm{~m} \text {, block } 4 / 76^{a} \text { haulage } \\
\text { drift }\end{array}$ & Rockburst $2.5 \mathrm{~m}^{3}$ \\
\hline 20.04 .90 & Kirovsk mine, Level +252 , block $13 / 15,13^{\text {a }}$ haulage drift & Rockburst $6 \mathrm{~m}^{3}$ \\
\hline 12.12 .90 & Kirovsk mine, Level+172, crosscut N 2 & Tectonic rockburst $15 \mathrm{~m}^{3}$ \\
\hline 18.05 .92 & $\begin{array}{l}\text { Kirovsk mine, Level+252, block 13/15, } 14 \text { haulage drift, } 13 \\
\text { drill-undercutting drift }\end{array}$ & Rockburst $5 \mathrm{~m}^{3,}, \mathrm{E}=3 \cdot 10^{7} \mathrm{~J}$ \\
\hline 05.07 .92 & $\begin{array}{l}\text { Rassvumchorr mine, level }+530 \mathrm{~m} \text {, block } 14 / 1614^{\mathrm{b}} \text { haulage } \\
\text { drift }\end{array}$ & Rockburst $\mathrm{M}=1$ \\
\hline 16.12 .92 & $\begin{array}{l}\text { Yuksspor mine, level }+460 \mathrm{~m} \text {, block 15/18, } 31 \text { drill-undercut- } \\
\text { ting drift }\end{array}$ & Rockburst $0,5 \mathrm{~m}^{3}$ \\
\hline 06.03 .93 & $\begin{array}{l}\text { Rassvumchorr mine, level }+470 \mathrm{~m} \text {, crosscut } \mathrm{N} 1 \text {, explosives } \\
\text { storage, southern haulage drift } \mathrm{N} 1\end{array}$ & $\begin{array}{l}\text { Tectonic rockburst, rock inrushes of } 25 \mathrm{~m}^{3} \text { and fractures in } \\
\text { concrete lining } \mathrm{M}=2.5\end{array}$ \\
\hline 12.04 .93 & $\begin{array}{l}\text { Kirovsk mine, level }+252 \mathrm{~m} \text {, block } 4 / 826 \text { drilling cross drift, } \\
12 \text { drilling drive, } 18 \text { drill-undercutting cross drift }\end{array}$ & Rockburst $13 \mathrm{~m}^{3}$ \\
\hline 25.05 .93 & $\begin{array}{l}\text { Kirovsk mine, level }+252 \mathrm{~m} \text {, block } 4 / 8,21 \text { drilling drive, } 13 \\
\text { drill-undercutting drive }\end{array}$ & Rockburst $11 \mathrm{~m}^{3}$ \\
\hline 17.11 .93 & Kirovsk mine, level $+252 \mathrm{~m}$, block $4 / 8$ & Mining-induced earthquake $10^{10} \mathrm{~J}(\mathrm{M}=3.8)$ \\
\hline 09.12 .93 & Kirovsk mine, level $+252 \mathrm{~m}$, block $4 / 8$ & Mining-induced earthquake $M=1.7$ \\
\hline 12.12 .93 & Kirovsk mine, level $+252 \mathrm{~m}$, block $4 / 8$ & Mining-induced earthquake $M=3.0$ \\
\hline 19.05 .94 & Rassvumchorr mine, level $+470 \mathrm{~m}$, block $14 / 19$ & Tectonic rockburst $3.5 \mathrm{~m}^{3}$ \\
\hline 28.05 .94 & $\begin{array}{l}\text { Kirovsk mine, level }+252 \mathrm{~m} \text {, block } 7 / 9,7^{\mathrm{a}} \text { haulage cross } \\
\text { drift }\end{array}$ & Rockburst $10 \mathrm{~m}^{3}$ \\
\hline 03.08.94 & Kirovsk mine, level $+252 \mathrm{~m}$, block $7 / 9,7$ haulage cross drift & Rockburst $15 \mathrm{~m}^{3}$ \\
\hline
\end{tabular}




\begin{tabular}{|c|c|c|}
\hline 16.09 .94 & $\begin{array}{l}\text { Kirovsk mine, level }+252 \mathrm{~m} \text {, block } 7 / 9,7 \text { haulage cross drift } \\
\text { and } 6^{\mathrm{b}} \text { control-air cross drift }\end{array}$ & Rockburst $16 \mathrm{~m}^{3}$ \\
\hline 26.10 .95 & $\begin{array}{l}\text { Junction zone of Rasvumchorr and Open pit of Tsentralny } \\
\text { mine mines, orepass N } 4 \text { of the Central mine }\end{array}$ & Mining-induced earthquake $M=4.5$ \\
\hline 09.07 .98 & $\begin{array}{l}\text { Open pit of Tsentralny mine mine, junction of orepass N } 4 \\
\text { chamber with transport gallery }\end{array}$ & Tectonic rockburst Fractures in solid concrete lining \\
\hline 18.09 .98 & Rasvumchorr mine, level+ 517 m, block 6/8 & Rockburst $1.5 \mathrm{~m}^{3}$ \\
\hline 14.11 .99 & $\begin{array}{l}\text { Junction zone of Rasvumchorr and Open pit of Tsentralny } \\
\text { mine mines, orepass N } 6 \text { of the Central mine; administra- } \\
\text { tion and municipal buildings of Rasvumchorr mine; town } \\
\text { of Kirovsk }\end{array}$ & Mining-induced earthquake $M=2.8-3.5$ \\
\hline 15.02 .01 & $\begin{array}{l}\text { Kirovsk mine, level }+172 \mathrm{~m} \text {, block } 10 / 14 \text {; drilling and } \\
\text { transportation cross drifts } 513,514,515 \text {; eastern haulage } \\
\text { drift, level }+252 \mathrm{~m}\end{array}$ & $\begin{array}{l}\text { Tectonic rockburst, significant destructions of drilling-trans- } \\
\text { portation cross drifts, Fractures in sputting concrete lining }\end{array}$ \\
\hline 24.10 .02 & $\begin{array}{l}\text { Rasvumchorr mine, level }+492 \mathrm{~m} \text {, block } 6 / 8 \text {; drilling-under- } \\
\text { cutting cross drift } 1 / 8\end{array}$ & $\begin{array}{l}\text { Rockburst } 0.5 \mathrm{~m}^{3} \text { from roof in the block between discharge } \\
\text { cleft and oxidized zone }\end{array}$ \\
\hline 11.05 .03 & $\begin{array}{l}\text { Yuksporr part of the united Kirovsk mine, haulage drift } 4 \text {, } \\
\text { south-western haulage drift }\end{array}$ & $\begin{array}{l}\text { Mining-induced earthquakes. Loosened rock falling in the } \\
\text { form of flat plates; the energy of the main seismic event made } \\
E=9 \cdot 10^{9} \mathrm{~J}\end{array}$ \\
\hline 11.10 .03 & $\begin{array}{l}\text { Open pit of Tsentralny mine mine, auxiliary working leading } \\
\text { to orepass } N 6 \text { at level }+450 \mathrm{~m}\end{array}$ & $\begin{array}{l}\text { Tectonic rockburst. Dynamical formation of loosened rock } \\
\text { at the southern wall of the working and at the junction of the } \\
\text { southern wall with the roof }\end{array}$ \\
\hline
\end{tabular}

